\title{
PSYCHOSOCIAL ASPECTS OF MAMMARY CARCINOMA
}

\section{CHARLOTTE SEARLE}

Professor and Head - Department of Nursing Science - University of South Africa (Paper given at the Medical Student's Congress - University Pretoria, 1 April, 1980)

\section{OPSOMMING}

Gesondheidsprofessioneles moet aandag gee aan die lewensbelangrike rol wat sielkundige kwessies in die oorlewing van die persoon met borskanker speel. Dit is belangrik om te onthou dat wat so hoogdrawend "sielkundige aspekte" genoem word, op stuk van sake niks anders is as eensaamheid nie, 'n gevoel van verwerping, 'n bekommerde gees, vrees, die stryd ten opsigte van ekonomiese druk en huislike spannings, die las van die behandeling en die oorlewingstryd van' $n$ gewone mens wat beangs is en na die gesondheidsprofessioneles vir hulp in sy stryd teen die meedoënlose siekte opsien.

$\mathbf{M}$ alignant neoplastic diseases in man are as old as mankind itself. The Hindu epic, Ramayana, dating back to c $2500 \mathrm{~B} \mathrm{C}$, described tumours and their treatment. Since then Hippocrates (c 460 - 375 B C), Celsus (c 30 B C - A D 38), Galen (c 130 - 200 A D) and Leonides of Alexandria (c 180 A D), and numerous other scientists have studied and recorded these phenomena. Heller from the National Cancer Institute stressed that "Man's attempt to understand cancer and to find ways of preventing, controlling and curing it began in ancient times". (Heller, 1960)6

Whilst tremendous progress has been made in this century in some aspects of the fight against cancer, there are some aspects that have received inadequate attention.

The psychosocial impact of cancer does not receive the attention it deserves, and this partial deficit inevitably slows the progress of the onslaught against this disease. McAleer and Kluge (1975) ${ }^{14}$ maintain that this is due to the fact that "cancer research and treatment emphasize the search for ultimate cures for the disease process and a variety of treatment methodologies to control the disease. As a result there has been a lack of emphasis on the psychosocial parameters related to cancer'. Cancer associations in the western world are attempting to focus attention on this dimension of cancer treatment and care but it appears that researchfunding for this purpose is negligible. Rehabilitation counsellors also maintain that enough emphasis is as yet not being laid on psychosocial dynamics in relation to the quality of survival, because research into this aspect of treatment is negligible. Evidence to date is mostly of an empirical nature.

There is obviously a clamant need for research in this field. Whilst the foregoing is said to constitute a par- ticular problem in all cancer care, it is of particular importance in cancer of the breast, because of the high incidence of this disease.

Rosello, Welty and Graham $(1973)^{20}$ grouped the potential psychosocial stresses and losses facing all cancer patients as:

" - those induced by the disease itself, such as: loss of health; feelings of shame, punishment or retribution and feelings of loss of control and impending death

- those related to therapy such as: fear of injury and mutilation; pain; and change in appearance

- those related to hospitalization, such as impairments in: relationships with family, friends and usual surroundings; employment, many pleasures and identity".

They suggest that such coping mechanisms as denial, withdrawal, rationalization, intellectualization, suppression, compensation and regression are used extensively by all cancer sufferers. Lynch and Krush (1968) ${ }^{12}$ believe that denial is the primary defence mechanism used by cancer sufferers. Lazarus (1966) ${ }^{10}$, Peck (1972) ${ }^{19}$ and Lipowski (1972) 11 have all stressed anxiety, denial, depressive effect, guilt and anger as the primary emotional reactions manifested by cancer patients. This has a profound effect on early diagnosis, acceptance of diagnosis, co-operation in treatment, acceptance of side-effects of treatment, adjustment of life-style and hence on the quality and duration of survival.

The person with breast cancer exhibits the same coping mechanisms as other cancer patients, but her fear and insecurity are heightened by other issues.

A woman's breasts have great socio-cultural significance in western society. They are viewed as objects of desired beauty. Loss or threatened loss of a 
breast is a traumatic experience. Mind and body function as a closely integrated unit. A change in body image and identity concept, a possible loss of feminity, of selfesteem and of sexuality have a devastating mental effect. The whole person is affected, not just the particular organ. The emotional response of the woman who has to lose a breast is a mix of many scarifying factors. There is confusion and uncertainty about her concept of self and of her body image and what loss of a desirable part of her body will do to her relationships with the opposite sex and with family and friends. Tiedt $(1975)^{26}$ believes that in many cases the woman who has had a breast removed may be more concerned with her loss of feminine identity than with the possible threat to her life. She believes that the ability to come to terms with this threat to feminine identity is the beginning of acceptance of the realities of the disease and all that this will imply for the individual.

Let us not under estimate the emotional impact of the diagnosis of breast cancer. It is a frightening human experience. It is probably the loneliest period in the life of any woman. The suspense of waiting for the results of the biopsy, the lack of free discussion by the doctor, and the conspiracy of silence by family and friends compound the ever present fear of inevitable and unendurable pain, of disfigurement and of early death. There is an instinctive fear of what the diagnosis of breast cancer will mean in coping with interpersonal relationships with husband, family, friends, co-workers and members of the health team, as well as of what it will mean in terms of: role change and role image, physical and emotional endurance, the economic drain on the family and the possible loss of a key figure in the family. There is often self-blame, inferred guilt, a belief in punishment for wrong-doing or in personal failure in life and there is the unanswered cry "why me?". There is a pervading sense of helplessness.

Much of this fear stems from ignorance, from folklore and from lack of clear communication by the doctor. There is consensus among contemporary authors on the psychosocial dynamics of cancer that is also largely due to the fact that the majority of persons in western society look upon cancer as a disease synonymous with death. The belief exists that man is powerless against cancer and that it is characterized by excruciating and non-relievable pain. There is the haunting fear, that whatever the modality of treatment, whatever the sacrifices made by the family and the loved ones, and despite the prediction of a good prognosis, one will never be finished with it. One will never be able to feel that the disease has been overcome. Deep in the recesses of the mind the awareness exists that there will always be a possibility of recurrence of the disease. Recurrence and the fear of this is a very realistic problem. Too often the patient cannot share these thoughts with her family, or her doctor, for fear they may think she is morbid, and for fear of estranging them from her.

There is general consensus in the literature that patients dread discussion of the issue with relatives, and they in turn refrain from mentioning the subject for fear of distressing her. This on the other hand may make her feel that they are not concerned about her and so the vicious cycle of anxiety and non-communication is perpetuated.
Tiedt $(1975)^{26}$ believes that patients' behaviour response to cancer is determined by their general pattern of life and by "a constellation of historical, familial, environmental, religious and cultural factors" inherent in their life-style. Tiedt and other authors believe that society places an enormous stigma on cancer whilst placing great value on an intact and healthy body. This attitude influences, consciously and unconsciously, the response to the diagnosis and treatment by all cancer patients, and in particular influences the attitudes of the woman with breast cancer.

There is general consensus that the personality of the person is a very important factor in her response to the diagnosis and treatment of breast cancer. The woman with a negative personality generally exhibits a pronounced tendency to self-pity and a marked inability to accept the situation. She is unable to forgive relatives for their seeming inability to understand her problem and is unable to develop and maintain supportive relationships in her time of crisis. The result is frequently very stressful, for relatives and friends develop feelings of ambivalence and even of outright rejection. This is particularly the case when the extensiveness of treatment or the poor prognosis exercises a heavy drain on the economic and emotional resources of the family. Because she herself is unable to develop and maintain supportive relationships in this time of crisis, and because she over-extends her poor self-image, she virtually cultivates an inability to cope with the crisis. This leads to multiple problems in her treatment and care and minimises her chance of meaningful survival. The more this type of personality and her family realize that they are unable to control the sequence of events associated with the course of the disease, the more will her anxiety and hostility increase and the greater will be the negative impact on treatment. Such a personality cannot cope with issues such as loss of income, heavy health care bills, length of illness, pain, mutilation, side-effects of treatment, fear of death, rejection of family and friends and dependency on others.

On the other hand, the woman with a positive personality herself initiates the first step towards effective rehabilitation and of ensuring the quality of survival. She avoids psychologic invalidism, accepts the diagnosis and proposed treatment and helps her family to cope with their fear, anxiety and feelings of ambivalence. This strenthens their support of her, prevents oversolicitousness and of rejection of her. Her decision to accept and co-operate with the aggressive therapy involved in all forms of cancer treatment, indicates that she has chosen to live and to play a meaningful part in the quality of her survival period even if this period should end in death. She is also ready to brace herself to face the final crisis of dying with dignity and courage.

However, it must be remembered that there is no clear-cut demarcation between negative and positive personalities and their approaches to the threat of cancer and its modalities of treatment. Both categories evince unexpected strengths or unexpected weaknesses, and both categories are subject to the same fears and anxiety. Simonton $(1975)^{23}$ after extensive study of the subject, came to the conclusion that most patients and their families have hidden or even overt negative 
feelings about treatment, whether this be surgery, radiation, chemotherapy, or hormone therapy. He believes that there is a latent feeling that almost nothing can be done to help in the fight against the disease. He believes that cancer victims and their families must be helped to combat this attitude and to develop a positive approach. He states "I can't see how any thinking person can help but see the relationship between what a person believes will happen as far as his treatment and disease are concerned and the eventual outcome'. Mind, body, emotion, act as a unit and the interaction between these three and the social situation in which the patient finds herself have tremendous meaning for recovery or for the quality of the survival time and of death.

Whichever way this question is looked at, it appears that the woman with breast cancer has a very real need for psychosocial support. This should start with the maintenance of an optimum therapeutic milieu by medical and nursing personnel. Doctors and nurses have a profound duty to nourish and support a hopeful atmosphere, and to inculcate in the woman acceptance of her problem, recognition of the importance of cooperation all the way with treatment, and a desire to live a meaningful life not only for herself, but also for her family, notwithstanding the grave disability she has to endure. They have to initiate positive thinking and action in the family, and lacking other services may have to be the ones to maintain this for it is part of the therapy of their patient.

These patients and their families have to be counselled and taught the ways of adapting to the problem. The family has to be helped to realise that practical help, encouragement, love and support are essential ingredients in the rehabilitative process. They have to be helped to analyse the problem and to find meaningful ways to cope with the crisis in their midst. The family must be helped to identify the resources in their community that will aid and enhance the recovery process and they have to be helped to support the life process of the patient so that optimal recovery becomes possible. Where this is not possible, optimal comfort and ease right up to and through the dying phase must be maintained. They must be helped to realize that the afflicted woman is not only facing the disease and the fears and anxiety associated with this, but also the treatment, and that her concept of body consciousness is an essential part of the will to live, whilst the effects of surgery, radiation or chemotherapy may be very distressing and debilitating. They must be helped to cope with the financial burdens of the disease and the altered role of a key member in the family.

Both patient and family must be helped to sort out the real from the unreal, to anticipate the future, and to discuss all the attendant problems. In short, both patient and family have to be educated to change their beliefs about the parameters of the disease and to identify and acknowledge their own strengths to cope with such a traumatic experience.

Whilst doctors and nurses have an inherent responsibility to initiate and reinforce these processes, they cannot do this alone. Assistance from pastoral psychologists, general counselling psychologists and social workers is vitally important. Whilst such assistance may be readily available at the State hospitals, the person who is a contributor to a medical aid scheme in South Africa is frequently denied the support of counselling psychologists and social workers. Private treatment for cancer is a long and costly business, which few middle class families can manage, hence private psychological counselling is out of reach of the average middle class person suffering from cancer of the breast even if she is a member of a medical aid scheme. Social workers other than the very few working in conjunction with the National Cancer Association, are not normally associated with the care of the private patient. Yet the need is there. World-wide emphasis is being placed on the development of counselling approaches dealing with death. Elizabeth Kubler-Ross saw to that. But modern cancer therapy requires that we should focus primarily on the life-sustaining needs of the patient. There is so much hope today. There is so much that can be done to help the patient to cope with the disease, the treatment, the family and the economic pressures, as well as with her own fears and anxiety. There is so much that could be done to help her to live a happy and a fruitful life.

Reach-for-recovery volunteers have an important role to play in helping the woman who has had a radical mastectomy to adopt a positive attitude towards her disability. But a great deal more is needed than voluntary assistance. Time is needed to listen to such a patient. Time and skill are needed to help her to cope with the many problems arising from the disease. Time and skill are needed to help her identify a recovery goal and to strive for it. Time and skill are necessary to help her towards a sense of future orientation. It is for this reason that doctors and nurses need the help of other workers in this field. Unfortunately such help is available only in the larger health care centres. This is the dilemma.

Because breast cancer, as indeed all other forms of cancer, constitutes a major health problem, the State should provide or extensively subsidise counselling personnel in all towns and cities where cancer patients, ir respective of their economic status, could be guided, free of charge, on how to manage the psychosocial problems related to their disease, and on how to obtain such social assistance as they may need. Such counsell. ing service could also be provided in co-operation with the National Cancer Association.

This would be a positive health support service that would have an economic spin-off, as well provide an important human support service for the person with cancer.

Health professionals need to give attention to the vital role of psychosocial issues in the quality of the survival of the person with breast cancer. It is important to remember that what are so grandiloquently called "psychosocial aspects", are after all the loneliness, the feelings of rejection, the troubled state of mind, the fears, the struggle with the economic burdens and family tensions, the burden of the treatment and the struggle for survival of an ordinary human being who is frightened and who looks to the health professionals for help in their fight against this relentless disease. 


\section{REFERENCES AND SELECTED BIBLIOGRAPHY}

1. Bouchard, R. and Owens, N.F. 1976: Nursing care of the patient with cancer. St. Louis C V Mosby Co. 159.177

2. Costello, A.M. 1979: Supporting the patient with problems related to body image. Kruse, L.C. et al Cancer 1979 431-436.

3. Harrell, H.C. 1972: To lose a breast American Journal Nursing 72: 676.

4. Harker, B.L. 1979: Cancer and communications problems: a personal experience

Kruse L.C. et al 1979 Cancer. St. Louis C V Mosby Co. 403-414.

5. Healy, J.E. Jr. 1977: Role of rehabilitation medicine in the care of patient with breast cancer. Cancer 28: 1666, 1971.

6. Heller, J. 1960: Trends in cancer research. Mod Med 28: 68 .

7. Hinton, J. 1973: Hearing cancer. Brifish Journal Med Psych 46, 105-112.

8. Kavanaugh, R.E. 1974: Facing death. Baltimore Med Penguin Books.

. Kuehn, P.G. 1969: Quality of survival of the cancer patient. Hartford American Cancer Society Connecticut Division.

10. Lazarus, R.S. 1966: Psychological stress and the coping process. New York McGrawHill.

11. Lipowski, Z.J. 1972: Advances in psychosomatic medicine in Psychosocial Aspects of physical illness. Vol. 8 New York. Albert Phiebig

12. Lynch, H.T and Krush, A.J. 1968: Attitudes and delays in cancer detection. Arch Environmental Health: 17, 204-209.

13. Magarey, C.J. 1972: Treatment of apparently early breast cancer. The Dilemma. Med J Aust 543-547
14. McAleer, C.A. and Kluge, C.A. 1978: Counselling needs and approaches for working with cancer patients. Rehabilitation and Counselling Bulletin.

15. McColleem, P.S. 1978: Adjustment to cancer: a psycho-social and rehabilitative process. Rehabilitation and Counselling Bulletin. March 216-223.

16. Miller, C.L., Denner, P.R. and Richardson, V.E. 1976: Assisting the psycho-social problems of cancer patients: a review of current research Int Journal Nrs Stud 13: 16I-166.

17. Moore, F.D. et al 1968: Carcinoma of the breast. Boston Little Brown Co.

18. Owen, M.L. 1972: Special care of the patient who has a breast biopsy or mastectomy. Nurses Clin. North'America 7: 373

19. Peck, A. 1972: Emotional reactions to having cancer. Cancer: 22, 284-299.

20. Rosello, R.H., Welty, M.S. And Graham, W.B. 1973: The patient with maxillo-facia cancer - psychological aspect. Nursing Clinics North America 8: 153-158.

1. Schonfield, J. 1972: Psychological factors related to delayed return to an earlier life-style in successfully treated cancer patients. J Psych Res $16,41-46$.

22. Skipper, J.K and Leonard, R.C.: Social interaction and patient care New York J.P. Lippincolt.

23. Simonton, O.C. and Simonton, S.C. 1975: Belief systems and management of the emotional aspects of malignancy. Journal Transpersonal Psych. $129-47$.

24. Spratt, J.S. and Donegan, W.L. 1967: Cancer of the breast. Philadelphia W B Saunders Co.

25. Thompson, M.R. 1978: Communication with patients and relatives in R. Tiffany ed. 1978. Oncology for nurses and health care professionals. London: George Allen 42-62. 26. Tiedt, E. 1975: The psycho-dynamic process of the oncological expetience. Nursing Forum XIV: 3, 264-277. 